\title{
Infeksiøs endokarditt ved Ålesund sjukehus 1997-2006
}

\begin{abstract}
Sammendrag
Bakgrunn. Infeksiøs endokarditt er en alvorlig sykdom hvor agens og de predisponerende faktorer har vært i endring, og hvor morbiditet og mortalitet fortsatt er høy. Det foreligger fire norske retrospektive undersøkelser om infeksiøs endokarditt, den siste publisert i 1998. Vi vil i denne artikkelen kartlegge etiologi, behandling og mortalitet $\mathrm{i}$ denne pasientgruppen ved vårt sykehus i en tiårsperiode.
\end{abstract}

Materiale og metode. Journalene til alle pasienter $\geq 18$ år innlagt i perioden 1.1. 1997-31.12. 2006 med relevante koder for infeksiøs endokarditt i ICD-9 og ICD-10 som hoved- eller bidiagnose ble gjennomgått med registrering av demografiske data, kliniske data og laboratoriedata.

Resultater. 57 personer fikk diagnosen endokarditt, 37 var menn. Gjennomsnittlig alder var 66 år, og gjennomsnittlig insidens var 6,3/100 000 per år. Gjennomsnittlig behandlingstid var seks uker, og den vanligste startkombinasjonen av antibiotika var penicillin og aminoglykosid (46\%). Hyppigste agens var Staphylococcus aureus (21\%). En eller flere komplikasjoner ble registrert hos 42 pasienter (74\%). Ni pasienter (16\%) døde i løpet av sykehusoppholdet.

Fortolkning. Insidensen av infeksiøs endokarditt ved Ålesund sjukehus ligger i det øvre området av hva som er rapportert i tidligere studier. Vi finner, i samsvar med andre publikasjoner, at stafylokokker nå er det hyppigste agenset. Pasientalder er økende relativt til tidligere norske publikasjoner. Mortalitet og morbiditet er forstsatt høy.

\section{Geeta Gulati}

Torstein Hole

torstein.hole@helse-sunnmore.no

Eigill Eide

Medisinsk avdeling

Ålesund sjukehus

6026 Ålesund
På verdensbasis er insidensen av infeksiøs endokarditt mellom 1,7-6,2 per 100000 per år (1). Det er mangel på større undersøkelser, og de systematiske gjennomgangene som finnes, viser stor variasjon fra land til land (2), og et annet klinisk bilde av sykdommen enn det som initialt ble beskrevet av Osler (3) og Horder (4). Det foreligger kun fire norske retrospektive undersøkelser om infeksiøs endokarditt (5-8), den siste fra Ullevål sykehus med et materiale på 68 pasienter, samlet fra 1988-1994 (8).

Historisk sett ble pasienter med revmatisk hjertesykdom rammet, og vanligste agens var Streptococcus viridans $(9,10)$. I dag er de vanligste risikofaktorene klaffesykdom hos eldre, intravenøst sprøytemisbruk, pasienter med hjerteklaffproteser og kirurgiske inngrep. $\mathrm{S}$ aureus er blitt det hyppigste agenset (1).

Infeksiøs endokarditt er en endovaskulær, bakteriell infeksjon av intrakardiale strukturer, inkludert infeksjon av de store intratorakale årene og intrakardiale fremmedlegemer (11). Det er som oftest snakk om en subakutt tilstand, men den kan også gi et fulminant forløp med hurtig nedbrytning av affiserte hjerteklaffer. Insidensen av endokarditt i Europa har vært stabil, men pasientgruppen er blitt eldre, en mindre andel har kjent hjertesykdom, og agens er endret $(12,13)$. En økende andel opereres, og det har vært en trend til lavere mortalitet i sykehus (12). Vi har liten kunnskap om hvordan tilstanden har utviklet seg i Norge de siste 10-20 årene. Det er for eksempel ikke kjent om agens i Norge skiller seg fra utenlandske data, og om diagnostikk og behandling er i samsvar med retningslinjene. I denne artikkelen kartlegges, ved en retrospektiv undersøkelse, etiologi, behandling og mortalitet hos pasienter med infeksiøs endokarditt innlagt ved Ålesund sjukehus i perioden 1.1. 1997-31.12. 2006.

\section{Materiale og metode}

Ålesund sjukehus har lokalsykehusfunksjon for ca. 90000 innbyggere. Årlige innleggelser i medisinsk avdeling lå på rundt 5000 pasienter i den aktuelle perioden, med en årlig økning rundt $1-2 \%$.

Journalene til alle pasienter $\geq 18$ år innlagt i perioden 1.1. 1997-31.12. 2006 med relevante koder for infeksiøs endokarditt i ICD-9 og ICD-10 (14) som hoved- eller bidiagnose i pasientregisteret til Ålesund sjukehus, ble i 2008 gjennomgått med systematisk registrering av demografiske data, kliniske data og laboratoriedata. Pasienter ble bare registrert én gang. Tilsendte epikriser for pasienter som initialt ble innlagt ved andre sykehus, ble gjennomgått. Det ble registrert om Dukes kriterier for endokardittdiagnosen var oppfylt hos den enkelte pasient (15) (ramme 1).

Data ble analysert i statistikkprogrammet SPSS 15. Normalfordelte data er gjengitt med gjennomsnitt og standardavvik i parentes. Ikke-normalfordelte data er gjengitt med gjennomsnitt, og minimum-maksimum-verdi i parentes. Kategoriske variabler presenteres som prosentandel av totalantallet. Forskjeller mellom gruppene ble undersøkt med t-test for normalfordelte variabler, og med khikvadrattest for kategoriske variabler. P-verdi $<0,05$ ble ansett som statistisk signifikant. Insidensen ble regnet ut fra at Ålesund sjukehus har et nedslagsfelt på ca. 90000 innbyggere, hvor det i løpet av en tiårsperiode ble innlagt 57 pasienter med infeksiøs endokarditt.

Studien er forelagt og godkjent av personvernombudet for forskning ved Helse Sunnmøre.

\section{Resultater}

Søk i pasientregisteret med ICD-koder for endokarditt resulterte i 91 pasienter. 33 ble ekskludert fra videre analyser pga. teknisk feilkoding. En ble ekskludert på grunn av lav alder. 57 pasienter ble inkludert og av disse var 37 menn (65\%). Gjennomsnittsalderen var 66 år (spredning 20-88 år). 43 (75\%) fylte Dukes kriterier for sikker endokarditt. Gjennomsnittlig insidens av infeksiøs endokarditt i den aktuelle perioden var 6,3/100 000 per år (variasjon 2,2-10,0/100 000/år). Vi fant ingen årstidsvariasjon (data ikke vist).

Hyppigste komorbiditet var klaffefeil, aterosklerotisk sykdom, hypertensjon, diabetes mellitus og atrieflimmer (tab 1), hvorav statistisk signifikant flere kvinner hadde diabetes mellitus (ni kvinner, $\mathrm{p}=0,04$ ). Totalt 44 pasienter hadde klaffefeil ved ekkokardiografi, sikker klaffefeil grunnet infeksiøs endokarditt ble funnet hos 23 .

\section{Hovedbudskap}

- Insidensen av infeksiøs endokarditt i Ålesund ligger i øvre område av det som er beskrevet i internasjonale studier

- Pasientenes gjennomsnittsalder er høyere enn i tidligere norske studier

- Mortalitet og morbiditet ved infeksiøs endokarditt er høy 
Venstresidig affeksjon ble funnet hos 50 pasienter $(88 \%)$. Affeksjon av aortaklaff ble funnet hos $32(56 \%)$ og affeksjon av mitralklaff hos 23 (40\%), det var ingen statistisk signifikant forskjell mellom affeksjon av klaffene. Fem hadde affeksjon av begge klaffene. 12 (21\%) hadde implantasjon av fremmedlegeme i hjertet $\mathrm{i}$ form av pacemaker eller kunstige hjerteklaffer. Seks (11\%) hadde endokarditt lokalisert på fremmedlegeme. Ved innkomst var den gjennomsnittlige kreatininverdien $153 \mathrm{mmol} / \mathrm{l}(44-1030$ $\mathrm{mmol} / \mathrm{l})$ og CRP $117 \mathrm{mg} / \mathrm{l}(3-383 \mathrm{mg} / \mathrm{l})$. De hyppigst presenterende symptomene er gjengitt $i$ tabell 2. Ingen statistisk signifikant forskjell ble funnet mellom kjønnene. Gjennomsnittlig liggetid og behandlingstid var henholdsvis 7,5 (SD 4) og seks (SD 3) uker. De som ble operert fikk gjennomsnittlig sju uker med antibiotikabehandling, mens de ikke-opererte pasientene fikk behandling i fem uker $(p=0,01) .44(77 \%)$ fikk antibiotika før verifisert diagnose med ekkokardiografi eller oppvekst av agens i blodkulturer, og $42(74 \%)$ måtte skifte antibiotika under behandlingsperioden, hovedsakelig på grunn av bivirkninger og resistenssvar. Vanligste startkombinasjon av antibiotika før

\section{Ramme 1}

Modifiserte Duke-kriterier for diagnostisering av infeksiøs endokarditt (15). Patologiske eller kliniske kriterier må ligge til grunne for sikker diagnose.

Sikker endokarditt

1. Patologiske kriterier

- Mikrobiologisk: påvist agens ved dyrking eller histologisk prøve fra lokal vegetasjon i hjertet eller fra en septisk emboli eller fra en intrakardial abscess eller

- Patologisk lesjon: histologisk bekreftet aktiv endokarditt av en vegetasjon eller intrakardial abscess

2. Kliniske kriterier

- To hovedkriterier eller

- Ett hovedkriterium og tre bikriterier eller

- Fem bikriterier

Hovedkriterium - mikrobiologi

A. Typiske bakterier i to blodkulturer (Streptococcus viridans, Streptococcus bovis, HACEK ${ }^{1}$ gruppen, Staphylococcus aureus eller enterokokker) med ikke påvist primærfokus eller

B. Persisterende positive blodkulturer, med en av bakteriene som nevnt i A tatt med 12 timers mellomrom, eller ved vekst i tre av tre eller i tre av fire blodkulturer hvor det er minst en time mellom den første og den siste prøven

Hovedkriterium - ekkokardiografi

A. Typiske ekkokardiografiske funn av vegetasjon loscillerende intrakardial masse på klaffer eller støtteapparat eller iatrogen komponent)

eller

B. Abscess

eller

C. Nyoppstått partiell løsning av klaffeprotese eller nyoppstått klaffeinsuffisiens løkning eller forandring av kjent bilyd er ikke tilstrekkelig)

Bikriterier

- Predisponerende hjertesykdom eller intravenøst stoffmisbruk

- Feber $\geq 38^{\circ} \mathrm{C}$

- Vaskulære fenomener: arteriell embolus, mykotisk aneurisme, intrakranial blødning eller petekkier

- Immunfenomen: glomerulonefritt, Oslers knuter, Roths flekker eller positiv revmatoid faktor

- Positive blodkulturer som ikke oppfyller hovedkriteriene, eller serologisk påvist infeksjon med mikrober aktuelle ved endokarditt

- Ekkokardiografi: funn forenlig med endokarditt, men fyller ikke hovedkriteriene

Diagnosen avvises dersom det finnes en alternativ diagnose som forklarer de kliniske funnene eller tilbakgang av symptomer ved antibiotikabehandling under fire dager, eller dersom man ikke finner patologiske forhold tilsvarende infeksiøs endokarditt ved kirurgi eller autopsi med antibiotikabehandling under fire dager. Endokarditt er fortsatt en mulighet dersom diagnosen ikke kan avvises, men samtidig ikke tilfredsstiller kriteriene for å være sikker.

${ }^{1}$ Haemophilus aprophilus, Haemophilus paraprophilus, Actinobacillus actinomycetemcomitans, Cardiobacterium hominis, Eikenella corrodens, Kingella kingae

diagnosen var stilt, var penicillin og aminoglykosid (26 pasienter, $46 \%$ ). En eller flere komplikasjoner var registrert hos 42 pasienter $(74 \%)$. Hjertesvikt og transfusjonstrengende anemi var de hyppigst forekommende komplikasjonene (tab 3). To av dem som ble transfundert hadde fra tidligere kjent transfusjonstrengende anemi.

37 hadde positiv blodkultur, og en fikk påvist agens via $\mathrm{PCR}$, som ga totalt 38 pasienter $(67 \%)$ med påvisbar mikrobe. 12 $(21 \%)$ hadde oppvekst av S aureus, og fem $(9 \%)$ av Enterococcus fecalis. Hos menn var forekomsten av $\mathrm{S}$ aureus og $\mathrm{E}$ fecalis like

Tabell 1 Komorbiditet hos 57 pasienter med infeksiøs endokarditt ved Allesund sjukehus 1997-2006

\begin{tabular}{lc} 
& Antall (\%) \\
\hline $\begin{array}{l}\text { Klaffefeil likke sikkert relatert } \\
\text { til endokarditt) }\end{array}$ & 21 (37) \\
\hline Aterosklerotisk sykdom & $18(32)$ \\
\hline Hypertensjon & $17(30)$ \\
\hline Diabetes mellitus & $16(28)$ \\
\hline Atrieflimmer & $11(19)$ \\
\hline Obstruktiv lungesykdom & $8(14)$ \\
\hline Kreft & $5(9)$ \\
\hline Hypotyreose & $3(5)$ \\
\hline Annet & $42(73)$
\end{tabular}

Tabell 2 Kliniske tegn og funn ved innkomst hos 57 pasienter med infeksiøs endokarditt ved Ålesund sjukehus 1997-2006

\begin{tabular}{lc} 
& Antall (\%) \\
\hline Forhøyet CRP & $53(93)$ \\
\hline Feber & $43(75)$ \\
\hline Bilyd & $36(63)$ \\
\hline Anemi & $33(58)$ \\
\hline Luftveissymptomer & $21(37)$ \\
\hline Atrieflimmer & $7(12)$ \\
\hline Utslett & $5(9)$ \\
\hline Ubehag i brystet & $3(5)$ \\
\hline Synkope & $2(4)$ \\
\hline
\end{tabular}

Tabell 3 Komplikasjoner hos 57 pasienter med infeksiøs endokarditt ved Ålesund sjukehus 1997-2006

\begin{tabular}{lc} 
& Antall (\%) \\
\hline Hjertesvikt & $15(26)$ \\
\hline Transfusjonstrengende anemi & $14(25)$ \\
Nyresvikt & $10(18)$ \\
\hline Emboli & $10(18)$ \\
\hline Hjerteinfarkt & $9(16)$ \\
\hline Multiorgansvikt & $2(4)$ \\
\hline Perikardvæske & $1(2)$
\end{tabular}


hyppig (fire pasienter, $11 \%$ ), S aureus var hyppigste agens hos kvinner (åtte pasienter, $40 \%$ ). Flere kvinner enn menn hadde oppvekst av $\mathrm{S}$ aureus $(\mathrm{p}=0,01)$. Fordeling av mikrobiologiske funn er gjengitt $i$ tabell 4 .

$\mathrm{Ni}(16 \%)$ av totalgruppen døde av sin endokarditt i løpet av innleggelsesperioden, 18 $(32 \%)$ av totalgruppen ble operert. Sammenliknet med dem som ikke ble operert hadde sju (39\%) av de opererte oppvekst av $\mathrm{S}$ aureus $(\mathrm{p}=0,03)$, ni $(50 \%)$ hadde aortainsuffisiens $(p=0,04)$ og tre $(17 \%)$ hadde negative blodkulturer $(\mathrm{p}=0,05)$. Sammenliknet med dem som ikke døde, hadde tre av de ni av dem med intrahospital mortalitet ikke oppvekst i blodkultur $(\mathrm{p}=0,90)$.

Fem av de 19 uten påvisbar mikrobe fylte Dukes kriteriene for sikker endokarditt. I totalmaterialet hadde 14 (25\%) fătt utført en ortopedisk eller kirurgisk prosedyre under seks måneder før innleggelsen, tre var i dialyse. Ekkokardiografi viste vegetasjoner hos $50(88 \%)$, abscess hos fem $(9 \%)$ og partiell løsning av klaffeprotese hos to (4\%).

\section{Diskusjon}

Gjennomsnittsalder for infeksiøs endokarditt i denne studien var 66 år mot 58 år i Ullevål-

Tabell 4 Mikrobiologiske funn hos 57 pasienter med infeksiøs endokarditt ved Ålesund sjukehus 1997-2006

Antall (\%)

Stafylokokker totalt

Staphylococcus aureus

Staphylococcus lugdunensis

Staphylococcus epidermis

Koagulasenegative stafylokokker

Streptokokker totalt

Streptococcus viridans

Streptococcus sangius

Streptococcus gruppe B

Hemolytisk streptokokk gruppe D

Streptococcus oralis

Streptococcus mitis (PCR-klaff)

Alfahemolytiske streptokokker

Enterokokker totalt

Enterococcus fecalis

Enterobacter cloacae

Enterococcus species

Enerococcus durans

Annet

Escherichia coli

Aerococcus viridans

Granulicatella adialens

HACEK ${ }^{1}$

Ingen oppveks

Haemophilus aprophilus, Haemophilus paraprophilus. Actinobacillus actinomycetemcomitans, Cardiobacterium hominis, Eikenella corrodens, Kingella kingae studien publisert i 1998 (8). Utviklingen med at en eldre befolkning rammes, samsvarer med andre studier $(16,17)$. Flertallet den gang og i dag er menn, noe som også er i overensstemmelse med internasjonale studier (1). I samsvar med tidligere undersøkelser gjort i Norge og internasjonalt $(1,8,18,19)$, er stafylokokker i økende grad årsak til endokarditt. Grunnen til dette settes i sammenheng med at $\mathrm{S}$ aureus ofte infiserer eldre pasienter $(8,2,13,20-22)$ samt personer uten kjent hjertesykdom (23). Det finnes imidlertid stor geografisk variasjon (2), og i noen artikler konkluderes det fortsatt med at streptokokker er vanligere enn stafylokokker (12).

Den vanligste startkombinasjonen av antibiotika var aminoglykosid og penicillin, og dette er i samsvar med anbefalinger fra Legemiddelhåndboka ved endokarditt med ukjent agens (24), mens europeiske retningslinjer anbefaler kombinasjon av aminoglykosid og vancomycin (11). Fire til seks uker er anbefalt behandlingslengde med antibiotika både i Norge og i Europa, og dette gjelder uavhengig av kirurgisk behandling. I vårt materiale fikk de som ble operert gjennomsnittlig antibiotika i sju uker, mot fem for dem som ikke ble operert.

I motsetning til tidligere publikasjoner fant vi at $\mathrm{S}$ aureus var hyppigst blant dem som ble operert $(\mathrm{p}=0,03)$, og statistisk signifikant flere kvinner enn menn hadde oppvekst av $\mathrm{S}$ aureus $(12,25)$. Det var ingen forskjell mellom kjønnene angående kirurgisk behandling $(12,25)$. I likhet med andre studier fant vi at signifikant flere kvinner enn menn hadde diabetes mellitus (25), men det var ellers ingen signifikante forskjeller mellom kjønnene.

I risikogruppen hadde vi ingen med tidligere gjennomgått giktfeber, men intravenøst stoffmisbruk ble registrert. Klaffefeil forårsaket av endokarditt var vanskelig å bedømme da man ofte ikke har ekkokardiografi før sykdommen ble diagnostisert.

Svakheten ved studien er den retrospektive vurderingen av journalopplysninger og det lave antallet pasienter. Styrken er den uselekterte populasjonen fra et lokalsykehus hvor en stor andel fyller Dukes kriterier for sikker infeksiøs endokarditt.

\section{Konklusjon}

Insidensen av infeksiøs endokarditt ved Ålesund sjukehus ligger i det øvre området av det som er beskrevet tidligere. Vi finner, i samsvar med andre publikasjoner, at stafylokokker nå er det hyppigste agens, og at pasient alder er økende relativt til tidligere norske publikasjoner. Mortalitet og morbiditet er forstsatt høy ved infeksiøs endokarditt.

Vi takker Camilla Uhlin Hansen for god hjelp ved datainnsamlingen. Arbeidet er finansiert av lokalt FOU-fond.
Litteratur

Beynon RP, Bahl VK, Prendergast BD. Infective endocarditis. BMJ 2006; 333: 334-9.

2. Tleyjeh IM, Abdel-Latif A, Rahbi H et al. A systematic review of population-based studies of infective endocarditis. Chest 2007; 132: 1025-35.

3. Osler W. Chronic infective endocarditis. Q J Med 1909; 1908-9: 219-30.

4. Horder T. Infective endocarditis with an analysis of 150 cases with special reference to the chronic form of the disease. Q J Med 1909; 2: 289-324.

5. Anker E. Bakteriell endokarditt. Tidsskr Nor Lægeforen 1979; 99: 701-3.

6. Gossius G, Gunnes P. Rasmussen K. Ten years of infective endocarditis: a clinicopathologic study. Acta Med Scand 1985; 217: 171-9

7. Lien EA, Solberg CO, Kalager T. Infective endocarditis 1973-1984 at the Bergen University Hos pital: clinical feature, treatment and prognosis. Scand J Infect Dis 1988; 20: 239-46.

8. Husebye T, Smith G, von der Lippe E et al. Infek siøs endokarditt ved Ullevål sykehus 1988-94. Tidsskr Nor Lægeforen 1998; 118: $222-5$.

9. Hollanders G, De Scheerder I, De Buyzere M et al. A six years review on 53 cases of infective endocarditis: clinical, microbiological and therapeutical features. Acta Cardiol 1988; 43: 121-32.

10. Hickey AJ, Wolfers J, Wilcken DE. Reliability and clinical relevance of detection of vegetations by echocardiography in bacterial endocarditis. $\mathrm{Br}$ Heart J 1981; 46: 624-8.

11. Horstkotte D, Follath F, Gutschik E et al. Guidelines on prevention, diagnosis and treatment of infective endocarditis executive summary; the task force on infective endocarditis of the European society of cardiology. Eur Heart J 2004; 25 . 267-76.

12. Hoen B, Alla F, Selton-Suty C et al. Changing profile of infective endocarditis: results of a 1-year survey in France. JAMA 2002; 288: 75-81.

13. Delahaye F, Goulet V, Lacassin F et al. Characteristics of infective endocarditis in France in 1991. A 1-year survey. Eur Heart J 1995; 16: 394-401.

14. KITH. ICD 9 og ICD 10. www. kith.no (23.6.2009)

15. Durack DT, Lukes AS, Bright DK. New criteria for diagnosis of infective endocarditis: utilization of specific echocardiographic findings. Am J Med 1994; $96: 200-9$.

16. Hill EE, Herijgers P, Claus P et al. Infective endocarditis: changing epidemiology and predictors of 6-month mortality: a prospective cohort study. Eur Heart J 2007; 28: 196-203.

17. Cantrell M, Yoshikawa TT. Infective endocarditis in the aging patient. Gerontology 1984; 30: 316-26.

18. Mylonakis E, Calderwood SB. Infective endocard itis in adults. N Engl J Med 2001: 345: 1318-30.

19. Fowler VG jr, Miro JM, Hoen B et al. Staphylococcus aureus endocarditis: a consequence of medical progress. JAMA 2005; 293: 3012-21. Rettelse i: JAMA 2005; 294: 900.

20. Steckelberg JM, Melton LJ 3rd, Ilstrup DM et al. Influence of referral bias on the apparent clinical spectrum of infective endocarditis. Am J Med 1990; 88: 582-8

21. Watanakunakorn C. Staphylococcus aureus endocarditis at a community teaching hospital, 1980 to 1991. An analysis of 106 cases. Arch Intern Med 1994; 154: 2330-5.

22. Sanabria TJ, Alpert JS, Goldberg R et al. Increasing frequency of staphylococcal infective endocarditis. Experience at a university hospital, 1981 through 1988. Arch Intern Med 1990; 150: 1305-9.

23. Kaye $D$. Changing pattern of infective endocarditis. Am J Med 1985; 78 (6B): 157-62.

24. Norsk legemiddelhåndbok. www.legemiddelhånd boka.no (23.6.2009)

25. Aksoy O, Meyer LT, Cabell CH et al. Gender differences in infective endocarditis: pre- and comorbid conditions lead to different management and outcomes in female patients. Scand J Infect Dis 2007; 39: $101-7$

Manuskriptet ble mottatt 6.3. 2009 og godkjent 1.7. 2010. Medisinsk redaktør Åslaug Helland. 